\title{
Analysis of Good Corporate Governance and Corporate Social Responsibility Disclosure on Cost of Equity Capital in Listing CGPI and BEI 2013-2017
}

\author{
Angela Dirman \\ Accounting Study Program, Faculty of Economics and Business, University of Mercu Buana, Jl.Raya Meruya \\ Selatan Kembangan West Jakarta, Indonesia
}

\begin{abstract}
The research objective to be achieved is to provide understanding and knowledge to the public, especially investors and creditors regarding the application of good corporate governance and corporate social responsibility disclosure to the cost of equity capital and can be used as a reference for future researchers and stakeholders (investors, creditors and the government) in making relevant and reliable decisions. The method used is quantitative research with secondary data taken from IICG and annual reports on IDX as well as company websites with data collection techniques using purposive sampling method. Analysis of the data used is multiple linear regression. The research population is the issuers participating in the Indonesian Institute of Corporate Governance (IICG) and listing on the Indonesia Stock Exchange during the observation period of 2013 to 2017 . The sample in this study amounted to 45 with 9 issuers each year. The results of this study indicate that the application of good corporate governance has a positive effect on the cost of equity capital, and corporate social responsibility disclosure has a negative effect on the cost of equity capital.
\end{abstract}

Keywords: good corporate governance, corporate social responsibility, cost pf equity capital

DOI: $10.7176 /$ RJFA/10-16-04

Publication date: August $31^{\text {st }} 2019$

\section{Introduction}

The company gets capital to finance its operational activities through two ways, namely through debt and company equity (Keown et al, 2005). Debt is obtained from creditors who give loans to companies and get returns in the form of interest. While equity is obtained from investors who invest their capital in the form of shares and get returns in the form of dividends or capital gains. For companies, the total amount to be paid for all capital obtained is called the Cost of Capital which is divided into two, namely the Cost of Debt and the Cost of Equity (Dhany and Irawan, 2012).

Cost of Equity is defined as the shareholders' expectation of return from the capital invested in the company (Sirait and Sylvia, 2012). Investors will require the desired rate of return when investing. In other words it can be said that the cost of equity capital is the rate of return desired by investors. Cost of equity capital is closely related to investment risk in company shares (Wahyuni and Utami, 2018).

Corporate Governance (CG) is corporate governance that explains the relationship between various participants in the company that determines the direction and performance of the company (Monks \& Minow, 2001, in Wardhani, 2006). Since the economic crisis hit Indonesia in 1997, good corporate governance has been seen as increasingly important as a support for the sustainability of the company's business. The mechanism of good corporate governance applied can be used to reduce agency costs so as to reduce the cost of equity capital (Wahyuni and Utami, 2018).

In determining the cost of equity required the right decision taken by a manager to make the company's performance is getting better. According to Rebecca and Siregar (2014) the application of corporate governance means it is considered capable of increasing oversight of management to encourage effective decision making, preventing opportunistic actions that are not in accordance with company interests, and reducing information asymmetry between management, shareholders and creditors. The implementation of GCG (Good Corporate Governance) can also provide guarantees to investors on investments that have been invested so as to reduce the risk which will ultimately reduce the company's COC (Cost of Capital)

In addition to the implementation of good corporate governance, corporate sustainability will also be guaranteed if the company pays attention to the social and environmental dimensions. This causes companies as economic entities to be responsible not only to shareholders but also to the wider community

Reporting on corporate social responsibility (CSR) began to become a trend in Indonesia in the 2000s. In addition to the issuance of Law No.40 of 2007 concerning Limited Liability Companies which requires companies to report on social and environmental responsibility activities, increasing public demand that companies not only benefit from operations but also give something back to the community is one reason the growing development of CSR reporting in Indonesia.

Annual reports in Indonesia are mostly done voluntarily by companies. The company makes this disclosure 
to increase transparency between managers and stakeholders who use the annual report. Based on research conducted by Chen et al. (2009) states that corporate governance has a significant negative effect on the cost of capital in the market. Research by Rebecca and Siregar (2012) suggests that the effectiveness of the board of commissioners has no significant effect on the cost of equity while the audit committee tends to have a positive and significant effect on the cost of equity and corporate governance as measured by the corporate governance index has a significant negative impact on equity costs and debt costs. In Gusti's research (2013) which examines the effect of CSR disclosure on COC with institutional ownership as a moderating variable, it shows that there is an influence between CSR disclosure on COC. This shows that the more extensive the disclosure of CSR, the lower the COC.

Therefore based on this background, this study was prepared to examine the analysis of the implementation of good corporate governance and corporate social responsibility disclosure of the cost of equity capital. The difference between this research and previous research is to measure good corporate governance using data from The Indonesian Institute for Corporate Governance (IICG) in the form of ranking the Corporate Governance Perception Index. The Indonesian Institute for Corporate Governance (IICG) main objective is to encourage the creation of an ethical and dignified Indonesian business world through GCG practices. IICG itself has a CGPI research and warning program to encourage companies to improve the quality of the application of the concept of Corporate Governance through continuous improvement by carrying out benchmarking evaluations.

\section{LITERATURE REVIEW}

\subsection{Agency Theory}

Agency Theory is closely related to the relationship between management (agent) and shareholders (principal). According to Jensen and Meckling (1976) in Judge (2014) agency relationship is a relationship between management as an agent and investors as principals who both cooperate with each other, but in different positions using certain contracts or agreements. Conflicts between agents and principals will arise when there are differences in interests where the agent who is supposed to be responsible for the welfare of the principal, but tends to prioritize his own interests so that the interests of the principal.

The occurrence of these interests raises information asymmetry that can lead to agency costs that will affect the company's financial performance. Conflicts between managers and owners who are often called agency problems can be minimized by a supervisory mechanism namely the Good Corporate Governance (GCG) mechanism that serves as a tool to reduce or reduce agency costs and can lead to increased company disclosure.

The basic idea of managing agency theory provides a new perspective on corporate governance. The company is shown as a cooperative relationship between the principal (shareholder or owner of the company) and agent (management). Management's vested interest results in the need for a check and balance process to reduce the possibility of abuse of power by management. The mechanism that can be done to overcome this problem is by implementing good corporate governance (Good Corporate Governance). Good Corporate Governance (GCG) is a form of good corporate management, which includes a form of protection for the interests of shareholders (the public) as the owner companies and creditors as external funders. A good corporate governance system will provide effective protection for shareholders and creditors to get back on the investment as reasonable, appropriate and efficient as possible, and ensure that management acts as best as he can for the benefit of the company (The Indonesian Institute for Corporate Governance, 2004)

\subsection{Stakeholders Theory}

A shift in orientation from shareholders to stakeholders in the business world has been cited as the cause of the emergence of corporate social responsibility issues. Stakeholders are all parties, both internal and external who have a relationship that is both influential and influenced, directly or indirectly by the company (Reny and Danies, 2012). Gray et al. in Nur Cahyonowati (2003) suggested that stakeholder theory assumes that the existence of a company requires stakeholder support. The stronger the stakeholders, the more the company must adapt to stakeholders. Social disclosure is then seen as a dialogue between the company and stakeholders.

According to the stakeholder approach, the organization chooses to respond to the many demands made by the stakeholders, that is, each group in the environment outside the organization affected by the actions and decisions of the organization. According to this approach, organizations will seek to meet the environmental demands of groups such as employees, suppliers, investors, and the community (P. Robbins \& Mary Coulter, 1999). If the pressure from stakeholders is very strong and influences the continuity and performance of the company, then the company must be able to formulate policies and programs of social and environmental policies that are directed and integrated (Prasetyo, 2001). By expressing concern for the environment through financial reporting, the company in the long run can avoid huge costs due to demands from the public. Expenditures for social care disclosed to the public help indirect control over the company's business by the community. 


\subsection{Cost of Equity Capital}

Cost of equity capital (cost of equity capital) is the level of stock returns required by investors, namely the minimum rate of return desired by the fund provider (investor) to be willing to invest in the company (Utami, 2005). The task of financial managers is to have to know when and how much capital costs must be incurred to finance company investment (Arief, 2009). The concept of Cost of Capital is closely related to the required level of profit. If the company produces a return that is higher than the Cost of Capital, the return of the remainder will cause an increase in the value of the company's ordinary shares, and subsequently an increase in shareholder wealth. Conversely, if the internal rate of return is smaller than the Cost of Capital, the wealth of shareholders will decrease. (Keown et al, 2000, in Ryanto and Gusti, 2013).

Cost of Equity Capital is given as a risk compensation that investors are willing to take to invest in corporate capital. Based on the investor's perspective, there is a return that is expected to be obtained through dividends or an increase in the value of the given investment. The expected return or the cost of equity capital is related to the financial risk contained in the funds they invest in the company's business activities (Tanjung, 2014).

\subsection{Good Corporate Governance}

Good Corporate governance is a mechanism used to ensure that shareholders and corporate bondholders obtain returns from the activities carried out by managers with the funds they have invested / lend, or in other words, how financial suppliers companies control managers (Shleifer and Vishny, 1997). The Indonesian Institute of Corporate Governance (IICG) in Widya (2013) defines Corporate Governance as a process and structure implemented in running a company, with the main objective of increasing shareholder value in the long term, while still paying attention to the interests of other stakeholders. To achieve corporate governance In order to implement its principles, a good mechanism is needed to monitor all policies taken. Good corporate governance mechanisms can reduce agency problems.

In Indonesia there is an institution namely The Indonesian Institute for Corporate Governance (IICG) is an institution whose main activity is to conduct research into the implementation of Good Corporate Governance for companies whose results are the Corporate Governance Perception Index (CGPI).

\subsection{Corporate Social Responsibility Disclosure}

According to The World Business Council for Sustainable Development (WBCSD) defines CSR as a business commitment to contribute to sustainable economic development, through working with employees and their representatives, their families, local communities and the general public to improve quality of life in a beneficial way both for own business and for development. It can also be said that CSR cannot be separated from the interests of company shareholders and stakeholders, including company owners or investors, customers, employees, communities, suppliers, countries and the environment. Social responsibility more simply can be said as a reciprocal of the company to the community and the surrounding environment because the company has taken advantage of the community and the surrounding environment.

CSR does not provide financial reporting results in the short term. But CSR will have an impact, both directly and indirectly on the company's finances in the future. Implementing CSR consistently in the long run will foster a sense of community acceptance towards the company's presence. Conditions like that which in turn can provide economic-business benefits to the company concerned. Thus, if the company conducts CSR programs on an ongoing basis, the company will be able to run well. CSR should not be seen as a repressive demand from the community, but rather as the needs of the business world.

\subsection{Previous research}

Research conducted by Rebecca and Siregar (2012) shows that good corporate governance as measured by the index of good corporate governance has a negative impact on the cost of equity and debt costs.

El Ghoul et al (2011) examines how the performance of corporate social responsibility can affect the company's cost of capital. The results showed that companies that have good corporate social responsibility will have a low cost of capital.

Riyanto and Gusti's research (2013) which examines corporate social responsibility, cost of capital, and institutional ownership as moderating variables shows that the wider the disclosure of corporate social responsibility, the lower the company's cost of capital.

Nita Theresia (2018) examined the effect of the Effect of Good Corporate Governance Mechanisms on Equity Costs and Debt Costs, the results of her research showed that family ownership, independent commissioners and audit committees had no effect on equity costs, while institutional ownership proved to have a negative effect on equity costs.

Research by Suharsono and Rahmasari (2013) where the results of the study are that CSR influences COC, the more extensive the disclosure of CSR, the lower the COC. 


\subsection{Framework for Thinking}

\section{The Effect of Good Corporate Governance on the Cost of Equity Capital}

Research by Rebecca and Siregar (2012) that examines the influence of the Corporate Governance Index, Family Ownership, and Institutional Ownership on Equity Costs and Debt Costs shows the results that the Corporate Governance Index is proven to have a significant negative effect on the cost of equity and the cost of corporate debt. This shows that the quality of a company's corporate governance practices can reduce the cost of equity and the cost of debt. This can be caused because in the company another agency problem arises, namely between majority shareholders and minority shareholders. Information risk becomes greater when the majority shareholders have control in the company. Therefore, the return desired by investors is higher and increases the company's equity costs. Thus giving rise to an interesting suspicion that GCG disclosure has a significant effect on the cost of capital.

H1: Good Corporate Governance has a negative effect on the Cost of Equity Capital

\section{The Effect of Corporate Social Responsibility Disclosure on the Cost of Equity Capital}

The concept of cost of equity according to Sukarti and Suwarni (2018) is the cost paid in attracting investors to invest their money in company shares and retain these investors. Cost of equity is related to the risk of a company's stock investment. If the company's risk is low, it will make investors interested in investing their capital. So the cost of equity is important for investors in considering investment decisions for the company. Disclosure of Corporate Social Responsibility (CSR) through financial statements can provide more information to investors about the company and investors interested in investing their capital, so as to reduce the company's cost of equity.

A lot of literature confirms that CSR activities contained in corporate social disclosure can reduce the cost of capital of a company. Like the previous research conducted by El Ghoul, et al. (2011) found that companies that have good CSR will have a low cost of equity capital. Research conducted by Riyanto and Gusti (2013) by using variables of corporate social responsibility, cost of capital, and institutional ownership as moderating variables shows that the more widespread the disclosure of corporate social responsibility, the lower the cost of capital. Thereby raises interesting suspicion that CSR disclosure has a significant negative effect on the cost of capital.

H2: Corporate Social Responsibility Disclosure has a negative effect on the Cost of Equity Capital

Based on the study of theory and the results of previous research, the researcher can describe the framework of thought logically, flowing from the research problem, the theory used and the relationship between variables that reflect the facts / phenomena studied and are described as follows:

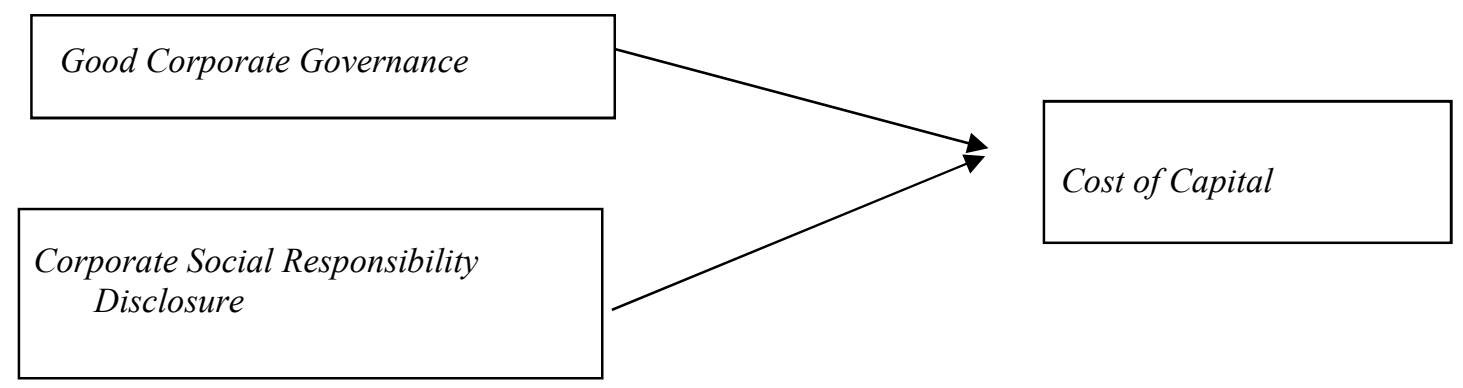

Thought Framework

\subsection{Hypothesis}

Based on the background of the problem, the formulation of the problem, the purpose of the study and literature review that has been described previously, the hypotheses to be tested in this study are as follows:

H1: Good corporate governance has a negative effect on the cost of equity capital

$\mathrm{H} 2$ : Corporate social responsibility has a negative effect on the cost of equity capital

\section{Research Method}

\subsection{Operational Definition of Variables}

According to Sekaran and Bougie (2013), variables are anything that can take different things or vary values. Values can be different at the same time the object or person is at the same time for different objects or people.

\section{Dependent variable}

Dependent variables, namely variables that are influenced or become a result due to the existence of independent variables. The dependent variable in this study is that used in this study is Cost of Equity Capital. The cost of equity capital is calculated based on the discount rate that investors use to assess future cash flow (Ohlson, 1995; Botosan, 1997; Botosan and Plumlee, 2002; Utami, 2005)

$\mathbf{P t}=\mathbf{y t}+\sum(1+\mathbf{r})-\mathbf{r E t}\{\mathbf{x r}+1-\mathbf{r B r}+\mathbf{t}+1\}$.

$r=1$

Information : 
$\mathrm{Pt}=$ Stock price in period $\mathrm{t}$

$B t=$ Book value per share period $t$

$\mathbf{x t}+1=$ profit per share

$r=$ expectation of cost of equity capital

To estimate earnings per share in period $t+1$, the Random Walk model is used as follows:

$\mathbf{E}\left(\mathbf{X}_{\mathbf{t}-1}\right)=\mathbf{X t}+\delta$.

Information:

$\mathrm{E}(\mathrm{Xt}-1)=$ Estimated earnings per share in period $\mathrm{t}+\mathbf{1}$

$\mathrm{Xt}=$ actual profit per share in period $\mathrm{t}$

$\delta=$ Term Drift used by the average change in earnings per sheet stock for 5 years

For the purpose of estimating earnings for the next year $(t+1)$, the average change in earnings per share for five years or since going public is used, if the issuer has not been even five years into a public company. Thus the estimated cost of equity capital in equation (1) can be simplified as follows:

$\mathbf{P t}=\mathbf{B t}+(\mathbf{1}+\mathbf{r})-\mathbf{1}\left[\mathrm{X}_{\mathrm{t}-1}-\mathbf{r B t}\right]$

$\mathrm{Xt}-1=$ earnings per share period $\mathrm{t}+1$ estimated by the random walk model as in equation (2).

After mathematically simplified equation (4) becomes:

$(\mathrm{Pt}-\mathrm{Bt})(1+\mathrm{r})=\left(\mathrm{X}_{\mathrm{t}-1}-\mathrm{r} \mathrm{Bt}\right)$

$\mathrm{r}=\left(\mathrm{Bt}+\mathrm{E}\left(\mathrm{X}_{\mathrm{t}-1}\right)-\mathrm{Pt}\right) / \mathrm{Pt}$

Information:

$\mathrm{Pt}=$ Stock price in period $\mathrm{t}$

$\mathrm{Bt}=$ Book value per share period $\mathrm{t}$

$\mathrm{E}(\mathrm{Xt}-1)=$ Estimated Earnings per share in period $\mathrm{t}+1$

$\mathrm{r}=$ Equity capital costs

Independent Variables

Good Corporate Governance

Good Corporate Governance is measured using the Corporate Governance index created based on analysis and surveys. The Corporate Governance Index used in this study is the Corporate Governance Perception Index published by the Indonesian Institute for Corporate Governance (IICG) between the observation periods of 2013 to 2017.

The GCPI assessment systematics (2013) consists of four stages, namely self-assessment, documentation system, paper assessment, and observation.

\section{CG = Corporate Governance Perception Index}

Disclosure of corporate social responsibility

In this study, the independent variable, CSR will be measured using Corporate Social Disclosure Index (CSDI). Information about the Corporate Social Disclosure Index (CSDI) to be used in this study is based on the G4 (Global Reporting Initiative) G4 obtained from the website www.globalreporting.org.

CSDI index calculations are carried out using a dichotomy approach, namely that each CSR item in the research instrument disclosed by the company is given a value of 1 and 0 if not disclosed (Vinta et al, 2016). Furthermore, the score for all items is added to obtain the overall score for each company. The CSDI calculation formulas are as follows (Vinta et al, 2016):

$$
\mathrm{CSDI}_{\mathrm{j}}=\frac{\sum \mathrm{X}_{\mathrm{ij}}}{\mathrm{n}_{\mathrm{j}}}
$$

Information:

CSDI: Corporate Corporate Disclosure Index $\mathrm{j}$

nj: number of items for company $\mathrm{j}, \mathrm{n}=91$

Xij: $1=$ if item $\mathrm{i}$ is disclosed; $0=$ if item $\mathrm{i}$ is not disclosed

\section{Population and Research Samples}

The population in this study were issuers participating in the Indonesian Institute of Corporate Governance (IICG) and listing on the Indonesia Stock Exchange during the observation period from 2013 to 2017. The sample in this study amounted to 45 with 9 issuers each year.

Method of Analysis

Data analysis method used in this research is quantitative analysis. Data analysis is needed to test the hypothesis, so that it can be seen the effect of the implementation of good corporate governance and corporate social responsibility disclosure with the Cost of Equity Capital. The analytical methods needed include:

1. Descriptive Statistics Analysis

Desktiptif statistics provide a description or description of a data that is seen from the average value (mean), 
standard deviation, variance, maximum, minimum and number of samples of each research variable.

2. Test of Classical Assumptions

This analysis can also be referred to as a prerequisite test of the multiple linear regression model that will be tested. A good regression model must produce a linear estimator not the best bias (Best Linear Unbias Estimator / BLUE). This condition will occur if it is fulfilled by several assumptions called classic assumptions such as normality test, multicollinearity test, heteroscedasticity test, autocorrelation test.

The regression model in this study is stated as follows:

$\mathrm{COEC}=\alpha+\beta 1 \mathrm{CGPI}+\beta 2 \mathrm{CSDI}+\mathrm{e}$

information:

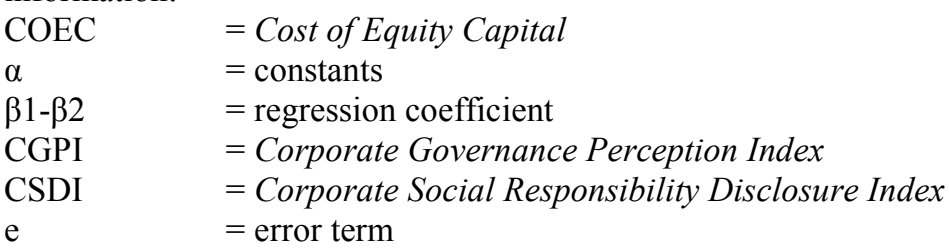

\section{Results}

\subsection{Descriptive Statistic}

Descriptive statistics are used to determine the level of implementation of Good Corporate Governance, Corporate Social Responsibility Disclosure, and Cost of Equity Capital. The measurements used in this study are the minimum value, maximum value, mean, and standard deviation.

\section{Descriptive Statistics}

\begin{tabular}{|l|l|l|l|l|l|}
\hline & $\mathrm{N}$ & Minimum & Maximum & Mean & Std. Deviation \\
\hline COC & 45 & -.7330 & 3.7790 & .370664 & .9105153 \\
CGPI & 45 & .8010 & .9386 & .872911 & .0298030 \\
CSR & 45 & .4505 & .8571 & .551502 & .1040432 \\
SIZE & 45 & 29.6958 & 34.6577 & 32.582085 & 1.7078886 \\
Valid N (listwise) & 45 & & & & \\
\hline
\end{tabular}

Source: Secondary data processed in 2019

From the descriptive statistical test results in table, the following information is obtained:

1. Cost of Equity Capital is the level of stock returns required by investors, namely the minimum rate of return desired by the fund provider (investor) to be willing to invest in the company (Utami, 2005). Based on the results of descriptive statistics testing in table 5.1 it can be seen that the COC variable has a range of values from - 0.7330 to 3.7790. The lowest Cost Of Equity Capital value is owned by PT Bank Central Asia Tbk. in 2014 with the company code BBCA, and the highest value was owned by PT Bukit Asam (Persero) Tbk. in 2015 with the company code PTBA. The average Cost of Equity Capital value is 0.370664 .

2. Corporate Governance is a system of internal control that is based on laws and regulations and ethical values regarding rights and obligations that are useful for increasing sustainable company value added as an economic or social entity for the long term and in its implementation. Based on the descriptive statistical test results in table 5.1 it can be seen that the CGPI variable which is a proxy of Good Corporate Governance has a range of values from 0.8010 to 0.9386 . The lowest CGPI value is owned by PT Timah (Persero) Tbk. in 2013 with the company code TINS, and the highest value was owned by PT Bank Mandiri (Persero) Tbk. in 2017 with the company code BMRI. The average CGPI value is 0.872911 .

3. Disclosure of corporate social responsibility is measured using the Corporate Social Disclosure Index (CSDI). The CSDI index calculation is done using a dichotomous approach where each CSR item in a research instrument disclosed by the company is given a value of 1 and 0 if not disclosed. The table above shows that the mean (mean) of 0.551502 means that the level of disclosure of corporate social responsibility in companies registered with GCPI and IDX is quite high at 55.1502\%. Variable Corporate Social Responsibility ranges from $45.05 \%$ to $85.71 \%$. The lowest value is owned by PT Bank Rakyat Indonesia (Persero) Tbk. in 2014 with the company code BBRI, and the highest value was owned by PT Aneka Tambang (Persero) Tbk. in 2014 with the company code ANTM. 


\subsection{Classical Assumption Test}

\subsubsection{Normality test}

One-Sample Kolmogorov-Smirnov Test

\begin{tabular}{|ll|l|}
\hline & & Unstandardized Residual \\
\hline N & & 45 \\
& Mean & $0 \mathrm{E}-7$ \\
& Std. Deviation & .83693268 \\
Most Extreme Differences & Absolute & .177 \\
& Positive & .177 \\
Kolmogorov-Smirnov Z & Negative & -.102 \\
Asymp. Sig. (2-tailed) & & 1.188 \\
\hline
\end{tabular}

a. Test distribution is Normal.

b. Calculated from data.

Source: Secondary data processed in 2019

Based on table above, it can be seen that the Kolmogorov-Smirnov $\mathrm{Z}$ value is 1.188 and the significance probability is $0.119>\alpha 0.05$ which means that the residual data is normally distributed.

\subsubsection{Multicollinearity Test}

\section{Coefficients}

\begin{tabular}{|c|c|c|c|c|c|c|c|}
\hline \multirow[t]{2}{*}{ Model } & \multicolumn{2}{|c|}{$\begin{array}{l}\text { Unstandardized } \\
\text { Coefficients }\end{array}$} & $\begin{array}{l}\text { Standardized } \\
\text { Coefficients }\end{array}$ & \multirow[t]{2}{*}{$\mathrm{t}$} & \multirow[t]{2}{*}{ Sig. } & \multicolumn{2}{|c|}{ Collinearity Statistics } \\
\hline & B & Std. Error & Beta & & & Tolerance & VIF \\
\hline \multirow{4}{*}{$\begin{array}{l}\text { (Constant) } \\
\text { CGPI } \\
\text { CSR } \\
\text { SIZE }\end{array}$} & 3.401 & 3.944 & & .862 & .394 & & \\
\hline & 14.550 & 7.455 & .476 & 1.952 & .058 & .346 & 2.890 \\
\hline & -3.558 & 1.883 & -.407 & -1.890 & .066 & .445 & 2.246 \\
\hline & -.423 & .156 & -.793 & -2.707 & .010 & .240 & 4.162 \\
\hline
\end{tabular}

\section{a. Dependent Variable: COC}

Source: Secondary data processed in 2019

The calculation results above show that the tolerance value shows that there are no independent variables that have a tolerance value of less than 0.10 , which means there is no correlation between the independent variables whose value is more than $95 \%$. The results of the calculation of the Variance Inflation Factor (VIF) value also showed the same thing that there was not one independent variable that had a VIF value of more than 10 (Ghozali, 2016). So, it can be concluded that there is no multicollinearity between independent variables in the regression model

\subsubsection{Autocorrelation Test}

Based on Table 5.4 it can be seen that the runs test produces a significance value of $t 0.071>0.05$, so it is concluded that autocorrelation does not occur in the regression model, thus assuming no autocorrelation has been fulfilled

Runs Test

\begin{tabular}{|l|l|}
\hline & Unstandardized Residual \\
\hline Test Value & -.29849 \\
Cases $<$ Test Value & 22 \\
Cases $>=$ Test Value & 23 \\
Total Cases & 45 \\
Number of Runs & 17 \\
Z & -1.807 \\
Asymp. Sig. (2-tailed) & .071 \\
\hline
\end{tabular}

a. Median

Source: Secondary data processed in 2019 


\subsection{Hypothesis Testing}

\subsubsection{Determination Coefficient Test}

Model Summary ${ }^{b}$

\begin{tabular}{|l|l|l|l|l|l|}
\hline Model & R & R Square & Adjusted R Square & Std. Error of the Estimate & Durbin-Watson \\
\hline 1 & $.394^{\mathrm{a}}$ & .155 & .093 & .8670117 & .979 \\
\hline
\end{tabular}

a. Predictors: (Constant), SIZE, CSR, CGPI

b. Dependent Variable: COC

Source: Secondary data processed in 2019

Table above shows that the coefficient of determination that shows the R-square value of 0.155 . This means that the $15.5 \%$ cost of equity capital can be explained significantly by the implementation of good corporate governance and corporate social responsibility disclosure. Whereas $(100 \%-15.5 \%)=84.5 \%$ the cost of equity capital can be explained by other variables.

\subsubsection{F test}

ANOVA ${ }^{\mathrm{a}}$

\begin{tabular}{|c|c|c|c|c|c|}
\hline Model & Sum of Squares & $\mathrm{df}$ & Mean Square & $\mathrm{F}$ & Sig. \\
\hline $\begin{array}{ll} & \text { Regression } \\
1 & \text { Residual } \\
& \text { Total }\end{array}$ & $\begin{array}{l}5.658 \\
30.820 \\
36.478\end{array}$ & $\begin{array}{l}3 \\
41 \\
44\end{array}$ & $\begin{array}{l}1.886 \\
.752\end{array}$ & 2.509 & $.072^{\mathrm{b}}$ \\
\hline
\end{tabular}

a. Dependent Variable: COC

b. Predictors: (Constant), SIZE, CSR, CGPI

Source: Secondary data processed in 2019

Based on table, it can be concluded that the variable implementation of good corporate governance and corporate social responsibility disclosure jointly influences the cost of equity capital, which means the model is fit for use in research that is seen with a sig value of $0.072<0.100$ (Gujarati, 2003)

\subsection{3 $\mathrm{T}$ test}

Coefficients $^{\mathrm{a}}$

\begin{tabular}{|l|l|l|l|l|l|}
\hline \multirow{2}{*}{ Model } & \multicolumn{2}{|l|}{ Unstandardized Coefficients } & Standardized Coefficients & \multirow{2}{*}{ Sig. } \\
\cline { 2 - 4 } & $\mathrm{B}$ & Std. Error & Beta & & \\
\hline \multirow{2}{*}{ (Constant) } & 3.401 & 3.944 & & .862 & .394 \\
1 CGPI & 14.550 & 7.455 & .476 & 1.952 & .058 \\
CSR & -3.558 & 1.883 & -.407 & -1.890 & .066 \\
\multicolumn{1}{l|l}{ SIZE } & -.423 & .156 & -.793 & -2.707 & .010 \\
\hline
\end{tabular}

a. Dependent Variable: COC

Source: Secondary data processed in 2019

Of the two independent variables included in the regression, the GCG variable showed a t value of 1.952 with a significance of $0.058<0.10$. This shows that GCG has a positive effect on COEC. And CSR shows a $t$ value of -1.890 with a significance of $0.066<0.10$. This shows that CSR has a negative effect on COEC,

\subsection{Discussion}

Based on the results of the multiple linear regression tests described previously, the discussion in this study concerning

\section{The effect of the implementation of Good Corporate Governance Against the Cost of Equity Capital}

Cost of equity capital is a return that can be expected by investors of a company if they invest in securities that have a comparable level of risk. The implementation of GCG can reduce agency problems and the risk of information asymmetry that occurs between companies and shareholders. The implementation of good corporate governance can increase the value of the company because it reduces the company's risk from management decisions that tend to prioritize personal interests (Rebecca and Siregar, 2012). Based on the results of the t test in this study, the variable Good Corporate Governance (GCG) has a positive effect on the Cost of Capital (COC). This shows that the application of corporate governance is considered capable of increasing oversight of management to encourage effective decision making, preventing opportunistic actions that are not in accordance with the interests of the company, and reducing information asymmetry between management, shareholders and creditors (Rebecca and Siregar, 2012). GCG is one of the important factors considered by investors in their investment decisions because the application of Good Corporate Governance can increase the Cost of Capital so that it will provide certainty of return on investment.

These results are in line with the research of Dian Antika, et al (2018) who examined the effect of the implementation of good corporate governance on the cost of equity and the cost of debt obtained results that good 
corporate governance affects the cost of equity.

Effect of Corporate Social Responsibility Information Disclosure on the Cost of Equity Capital

$\mathrm{T}$ test results indicate that the variable Corporate Social Responsibility (CSR) has a negative effect on the Cost of Equity Capital. This means that the disclosure of high Corporate Social Responsibility directly affects the Cost of Equity Capital, which shows that the existence of CSR information disclosed by companies in sustainability reporting affects investors' estimates of the risks that exist in the company. The higher the disclosure of CSR, the lower the information asymmetry between investors and managers. A low level of asymmetry shows that the less information that is hidden by the company, so the financial statements presented by the company will be more transparent. Transparent financial statements cause investor estimates of the risks that exist in the company to be low and the expected rate of return is also low, and ultimately will reduce the cost of equity capital.

This result is in line with research by Riyanto and Gusti (2013) who found a significant negative relationship between Corporate Social Responsibility Disclosure and the Cost of Equity Capital.

\section{Conclusion}

The implementation of good corporate governance has a positive effect on the cost of equity capital, and disclosure of corporate social responsibility has a positive and significant effect on the cost of equity capital

\section{Suggestions}

With the disclosure of future information, it is expected that issuers in Indonesia will become more active in updating information available on the website with a more advanced level of technology so that users can better know the information needed; using another index calculation or using another taxonomy; and using other issuers' sectors to be more comprehensive

\section{References}

Ashbaugh, H., Collins, D.W., Lafond, R. (2004). Corporate Governance and The Cost if Equity Capital. Papers.ssrn.com

Chen, K.C.W., Chen, Z., Wei, K.C.J. (2009) Legal Protection of Investors, Corporate Governance, and The Cost of Equty Capital. Papers.ssrn.com

Dian Antika Sari ; Nur Diana; M.Cholid Mawardi. 2018. Pengaruh Penerapan Good Corporate Governance Terhadap Biaya Ekuitas dan Biaya Utang. Riset Unisma.

El Ghoul, Sadok., Guedhami, Omrne., C.Y, Chuk., R.Mishra, Dev. 2011 Does Corporate Social Responsibility Affect The Cost of Capital? Journal of Banking and Finance 35, 2388-2406.

Graham, J. R., C. R. Harvey, \& S. Rajgopal. (2005). The economic implications of corporate financial reporting. Journal of Accounting and Economics, 40, 3-73

Gusti Ayu Putu. 2013. Pengaruh Pengungkapan CSR Terhadap COC dengan Kepemilikan Institusional Sebagai Variabel Pemoderasi. Jurnal ilmiah Akuntansi dan Humanika. Vol.2, No.2.

Izzo, M.F., and Magnanelli, B.S. (2012) Does it pay or does firm pay? The Relation Between CSR Performance and The Cost of Debt. Working Paper. Luiss University

Jensen, M.C., Meckling, W.H. (1976). Theory of The Firm: Managerial Behavior. Agency Cost and Ownership Structure Journal of Financial Economics, 3 (4), 305-360

Komite Nasional Kebijakan Governance (KNKG). (2013). Pedoman Umum Good Corporate Governance Indonesia. Komite Nasionl Kebijakan Governance. Jakarta

Nugroho.D.R,Meiranto.W. 2014. Pengaruh Good Corporate Governance Terhadap Biaya Ekuitas dan Biaya Utang (Studi pada perusahaan manufaktur yang terdaftar di BEI pada tahun 2010-2012). Diponegoro Journal of Accounting Vol. 3 (3):1-12

Paulinda, Vinta., dkk. 2016. "Pengaruh Pengungkapan Corporate Social Responsibility (CSR) Terhadap Earnings Response Coefficient (ERC)". Jurnal Akuntansi dan Keuangan, Vol.18, No.1, Mei 2016, 15-26.

Rebecca, Y., Siregar, S.V. (2014). Pengaruh Corporate Governance Index, Kepemilikan Keluarga, dan Kepemilikan Institusional Terhadap Biaya Ekuitas dan Biaya Utang: Studi Empiris pada Perusahaan Manufaktur yang Terdaftar di BEI. Simposium Nasional AKuntansi XVII Lombok.

Sekaran, U., Bougie, R. (2013). Research Methods for Business. Sixth Edition. Wiley \& Sons Ltd: United Kingdom

Shleifer, A., Vishny, R. (1997). A Survey of Corporate Governance The Journal of Finance LII (2)

Sirait, Shanty D.Y., dan Sylvia, V.S. (2012). Hubungan antara Biaya Modal Ekuitas dengan Tingkat Pengungkapan Tanggung Jawab Sosial dan Modal Intellectual pada Sektor Perbankan di Indonesia. Jurnal Akuntansi dan Auditing Volume: 9 No.1 November 2012:1-96

Suharsono, Riyanto Setiawan, dan Gusti ayu. (2013). Pengaruh Pengungkapan Corporate Social Responsibility Terhadap Cost of Capital dengan Kepemilikan Institusional Sebagai Variabel Pemoderasi. Jurnal Ilmiah Akuntansi, Vol.2, No.2, Juni 2013. ISSN 2089-3310 
Sukarti, dan Suwarti, Titiek. (2018). Pengaruh Pengungkapan CSR, Asimetri Informasi, Ukuran Perusahaan, dan Kepemilika Institusional terhadap Cost of Equity. Prosiding SENDI

Tanjung, F.A. (2014). Mengkaji Kelayakan Bisnis Menggunakan Cost of Capital. http://www.bglconline.com/ Sekaran, Uma. (2003). Research Method for Business A Skill Building Approach, $4^{\text {th }}$ Ed. New York: John Wiley and Sons.

Wahyuni, P.D., Utami, W. (2018). Pengaruh Good Corporate Governance dan Intellectual Capital Disclosure terhadap Cost of Equity Capital. Profita: Komunikasi Ilmiah Akuntansi dan Perpajakan. Vol.11 No.3. Desember 2018

Wardhani, Ratna. (2006). Mekanisme Corporate Governance dalam Perusahaan yang Mengalami Permasalahan Keuangan (Financially Distressed Firms), Simposium Nasional Akuntansi IX, Padang.

Utami, Wiwik. (2005). Pengaruh Manajemen Laba Terhadap Biaya Modal Ekuitas (Studi Pada Perusahaan Publik Sektor Manufaktur).Jurnal Riset Akuntansi Indonesia.Vol. 9, no.2, Mei 2006. 